\title{
Kliinisestä harjoittelusta työssäoppimiseen ja yhteistyötiimeihin
}

\author{
Ulla Talvitie, Sirpa Laitinen-Väänänen, Päivi Tikkanen
}

\begin{abstract}
Terveysalan työharjoittelun toteutumista on arvosteltu siitä, että oppilaitokset panostavat entistä vähemmän työharjoittelun ohjaukseen ja harjoittelupaikkojen kanssa tehtävään yhteistyöhön. Harjoittelussa perinteiset työtavat ja vallitseva työkulttuuri siirretään kritiikittömästi opiskelijoille. Koulun antamat tiedot ja harjoittelupaikan edellyttämät taidot eivät kohtaa. Artikkelissa luodaan näkymiä uudenlaiseen työssäoppimiseen tehostamalla koulun ja työpaikkojen välistä yhteistyötä.
\end{abstract}

$\mathrm{T}$ yöharjoittelu on nykyisessäkin ammattiin oppimisessa ja ammattiin sosiaalistumisessa keskeinen prosessi. Jossain määrin edelleen toimii perinteinen oppipoika ja mestari -suhde erilaisissa ammattitaidon oppimista vaativissa tilanteissa. Käsitys mestarin roolista vain on muuttunut vuosien saatossa mallin antajasta kriittisen ajattelun ohjaajaksi. Schön (1987) kuvaa mainiosti taidon oppimisen alueella ohjaajan merkitystä oppimisen edistäjänä. Taitava muusikko saattaa oppilaansa tilanteeseen, jossa oppilaalla on mahdollisuus kriittisesti tarkastella omaa osaamistaan. Mestari osoittaa, miten taitava soittaja kappaleen esittää, mutta samalla kun hän taitavasti todentaa osaamisen kriittisyyden oppilaalle, hän johdattaa oppilaansa etsimään itse omaa suhdettaan ja tulkintaansa kappaleeseen. Oppiminen tapahtuu tekemisen kautta niin, että luodaan yhä uudelleen uusi suhde harjoiteltavaan asiaan.

Työharjoittelua on alettu miettiä oppimispro- sessina, jossa ammatilliset valmiudet opitaan työn äärellä. Ammatillisessa oppimisessa korostetaan kontekstuaalisuutta, jossa oppilaan oma toiminta ja kokemus sekä toimintaympäristö muokkaavat oppilaan ammatillisen taidon oppimista. Ammatillisen kehittymisen katsotaan olevan mahdollista vain reflektiivisen praktiikan, kokemukseen ja käytäntöön perustuvan tiedon kautta (Järvinen ym. 2000). Miettinen (2000) tarkastelee työn oppimista erityisesti käytännöllisten ongelmien ratkaisemisena ja muutoksena yksilön ja ympäristön välisessä suhteessa. Oppiminen ja persoonallisuuden kehitys kytkeytyvät ympäristön muuttamiseen ja uusien toimintatapojen luomiseen. Niinpä myös opetustilanteet voivat uudistaa työelämää.

Ammatillisen koulutuksen järjestämisen perinteisessä mallissa opetus on hajautettu teoriaopetusta antavaan oppilaitokseen ja työharjoittelusta vastaaviin työelämän yksiköihin. Kivinen ja Silvennoinen (2000) esittävät epäilynsä siitä, että 
oppilaitoksissa todella opitaan niitä taitoja, joita koulutustutkintoa "vastaavaksi" ajatellussa ammatissa tarvitaan. He esittävät, että työmarkkinaongelmat ja riskit saattavat johtua yksilöiden puutteellisten taitojen ja työelämän tarpeiden välisestä kuilusta. Hakkarainen (1996) näkee teorian ja käytännön integroinnin ongelman liittyvän koulutuksen järjestämiseen siten, että useat lyhyet harjoittelujaksot jäävät erillisiksi suorituksiksi, jotka eivät pysty pureutumaan työtoiminnan kokonaisuuteen tai dynamiikkaan. Koulutuksessa välitetty uusi tieto ja siihen kytketty käytännön harjoittelu ei muuta työkäytäntöjä työpaikoilla.

Työssäoppimisen ajatuksena on ollut se, että tieto siirtyy oppilaitoksen ja työelämän välillä ja teoria ja käytäntö integroituvat ammatin hallinnan opiskelussa. Osaaminen ja tieto ei välttämättä kuitenkaan siirry tehtävästä toiseen ja vaarana on, että oppilaitokseen ja työpaikalle syntyy kaksi erillistä tietovarastoa (Tuomi-Gröhn 2000). Seuraavissa luvuissa käsitellään työharjoittelun järjestämistä fysioterapiakoulutuksessa. Artikkelissa arvioidaan fysioterapiatyön nykytilaa ja ammatillisia taitoja. Erityisesti pohditaan ammatillisten taitojen oppimista ja opetuksen järjestämistä niin, että oppilaitoksen ja työpaikan tiedot ja taidot pystytään järkevästi yhdistämään.

\section{Kliininen harjoittelu fysioterapiakoulutuksessa}

$\mathrm{H}$ arjoittelun osuus terveysalan ammattikorkeakouluopinnoista on yksi kolmasosa. Ammattitaitoa edistävän harjoittelun tavoitteena on perehdyttää opiskelija ohjatusti erityisesti ammattitaitojen kannalta keskeisiin käytännön työtehtäviin sekä tietojen ja taitojen soveltamiseen työelämässä. Ammattikorkeakoulujen harjoittelua koskevassa lainsäädännössä puhutaan ohjatusta harjoittelusta ja terveyskeskusten ja sairaaloiden henkilökuntia velvoitetaan antamaan ohjausta opiskelijoille harjoittelujaksojen aikana (Sairaaloiden ja terveyskeskusten kanssa tehtävät sopimukset käytännön opetuksesta 1994).

Vuosien saatossa harjoittelusta on käytetty erilaisia nimityksiä. Useimmiten harjoitteluun on

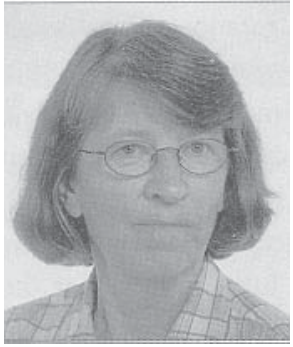

Ulla Talvitie

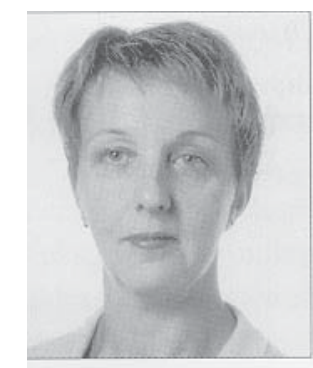

Sirpa Laitinen-Väänänen

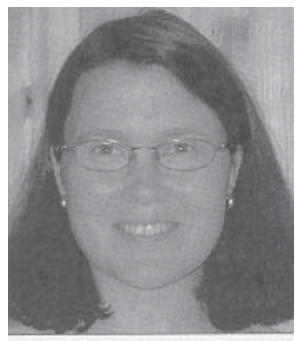

Päivi Tikkanen

liitetty viittaus käytäntöön tai käytännöllisyyteen (Konkola 2001). Vaikka virallinen nimitys on ollut käytännön harjoittelu tai ohjattu harjoittelu, on fysioterapiakoulutuksessa edelleenkin nähtävissä viitteitä nimen kliininen harjoittelu (clinical education) käytöstä. Englanninkielisessä kirjallisuudessa nimitys clinical education on yleisesti käytössä (Neville ja Crossley 1993). Nimitys viittaa perinteisiin harjoitteluympäristöihin, sairaaloihin ja niiden lääketieteellisesti määritettyihin osastoihin eli klinikoihin, jossa opiskelijat ovat suorittaneet harjoittelua. Harjoitteluympäristöt ovat vuosien varrella monipuolistuneet avopalvelua antaviin terveyskeskuksiin, kuntoutuslaitoksiin ja yksityisiin yrityksiin ja hoitolaitoksiin. Sairauden toteaminen on tavallisesti fysioterapiaan tulemisen syynä, vaikka fysiotera- 
pian avulla ei paranneta sairauksia, vaan pyritään edistämään toimintakykyisyyttä ja siten antamaan eväitä arkielämässä selviytymiseen. Silmäys fysioterapian ammattikorkeakoulujen opetussuunnitelmiin osoittaa, että edelleen käytetään palvelun käyttäjistä sairauksien mukaista jaottelua kuten tuki- ja liikuntaelinsairaat, hengitys- ja verenkiertohäiriöiset ja aisti- ja aivotoiminnan vaikeudet. Tässä artikkelissa käytetään käsitteitä työharjoittelu ja harjoittelu merkitsemään työelämässä tapahtuvaa harjoittelua.

\section{Työkäytännöt oppimisen kohteena}

\begin{abstract}
mmattikorkeakoulusta annetun asetuksen mu- kaisesti koulutuksella pyritään antamaan laaja-alaiset käytännölliset perustaidot ja ammatillisen toiminnan teoreettiset perusteet (Asetus ammattikorkeakouluopinnoista 1995, 7§). Koska koulutus toteutetaan useissa eri organisaatioissa, joudutaan pohtimaan kysymystä, miten opetuksen sisältö määräytyy eri koulutuspaikoissa. Onko koulun ja harjoittelupaikkojen näkemys työstä yhdenmukainen ja minkälaisen kuvan työstä opiskelija saa?
\end{abstract}

Harjoittelupaikat odottavat, että opiskelijat ovat saaneet tietoja ja taitoja, joilla on välitöntä hyötyä ja käyttöä työelämässä. Koulun ja työelämän erilaiset kulttuurit saattavat kuitenkin aiheuttaa ristiriitaa opetuksen järjestämisessä työpaikoilla (Cross 1995). Hentisen (1989) tutkimus hoitotyön koulutuksessa osoitti, että koulutuksen ja työelämän edustajien näkemykset erosivat siinä, mitä opiskelijoiden tuli oppia harjoittelun aikana. Opettajat pitivät tärkeänä sitä, että opiskelijat saivat harjoitella potilaiden kokonaishoitoa ja hoitotieteellisen tiedon soveltamista käytännön tilanteissa. Ohjaajat painottivat kädentaitojen oppimista, josta teoreettinen tieto jäi irralliseksi. Huntin ym. (1998a) tutkimuksessa vastavalmistuneet fysioterapeutit toivat esille koulun ja harjoittelupaikkojen välisen ristiriitaisuuden. Koulun antamat tiedot ja taidot eivät antaneet valmiuksia, joita työharjoittelupaikat edellyttivät. Erityisesti fysioterapeutit nostivat esille ongelmia kommunikaatiotaidoissa potilaan kanssa, taidoissa selviytyä työyhteisön ristiriitatilanteissa ja työpaikan hallinnollisia asioita koskevissa tiedoissa kuten työolosuhteiden järjestämisessä ja henkilöstöasioissa sekä yleisesti taloudellisten ja poliittisten ratkaisujen vaikutuksista terveyspalveluihin. Ammatilliset taidot he näkivät laajempina kuin pelkästään potilaan terapiaan kuuluviksi taidoiksi.

Koulutuksen kannalta oleellista on miettiä, minkälaista kuvaa opittavasta työstä opiskelijat saavat työharjoittelun aikana, jos työharjoittelun kokemukset todella vaikuttavat voimakkaammin kuin koulun antamat kokemukset ammatillisen identiteetin muotoutumisessa (Richardson 1999). Lähteenmäen (2001) mukaan fysioterapia opiskelijat pitivät harjoittelua ja sen tuomaa käytännön kokemusta ensisijaisena fysioterapiaa opettavana ja sen toteuttamista jäsentävänä tekijänä.

Fysioterapiaa koskevissa tutkimuksissa on todettu, että tekninen osaaminen on arvostettua, mutta terapiatilanteeseen liittyviä psyykkisiä ja sosiaalisia tekijöitä, joista ihmisten väliset vuorovaikutustilanteet rakentuvat, ei ole fysioterapiassa nähty tärkeinä terapiaan vaikuttavina asioina (Thornqvist 1994, Jorgensen 2000). Talvitie ja Reunanen (2002) tutkivat fysioterapeuttien ja potilaiden välistä vuorovaikutusta terapian aikana. Kommunikaation ja toiminnan analysointi osoitti, että potilailla oli hyvin vähän mahdollisuuksia osallistua aktiivisesti terapian suunnitteluun ja toteuttamiseen, fysioterapeutit toteuttivat terapian oman suunnitelmansa mukaisesti, eivätkä antaneet potilaiden terapian aikana tuomien kommenttien vaikuttaa siihen. Erityisesti potilailla, joilla oli puheen tuottamiseen tai ymmärtämiseen liittyviä ongelmia, oli vaikeuksia tulla kuulluksi ja ymmärretyksi. Hoitojen toteuttamisessa fysioterapeutit käyttivät runsaasti manuaalista ohjausta, mikä esti potilaiden omaehtoisen harjoittelun.

Useat tutkimukset osoittavat, että terveydenhuollossa vallitsee mekanistinen kuva ihmisestä, mikä merkitsee sitä, että asiakkaat ja terveydenhuollon henkilöstö toimii alisteisessa vuorovaikutussuhteessa ja vuorovaikutustilanteissa kommunikaatio on yksisuuntaista (Heath 1992; Heaven \& Maguire 1996). Roberts (1994) näkee, että 
mekanistinen toimintakulttuuri fysioterapiassa on peräisin alan toiminta- ja käyttäytymistapoihin vahvasti lähihistoriassa vaikuttaneesta biolääketieteellistä toimintakulttuurista. Stachura (1994) puhuu ammatillisesta dilemmasta, joka johtuu siitä, että biolääketieteellisen mallin omaksuminen on johtanut käden teknisten taitojen ylikorostumiseen ammattikäytännöissä.

Viitasen (1997) tutkimus osoitti, että terveyskeskuksissa toimivien fysioterapeuttien työkäytännöt olivat yksilöorientoituneita, mutta eivät asiakaskeskeisiä ja työkäytännöt olivat hyvin perinteisiä käsityömäisine työotteineen. Viitanen toteaa, että vallitsevilla työmenetelmillä on vaikea vastata tuki- ja liikuntaelinsairauksista kärsivien kuntoutukseen ilman ammattikulttuurin muuttamista.

\section{Ohjaajan ja opettajan roolit työharjoittelussa}

$\mathrm{T}$ yöharjoittelua koskevan tutkimuksen avulla on pyritty löytämään hyvän opettajan ja ohjaajan ominaisuuksia. Fysioterapiaa koskevissa tutkimuksissa on erityisesti pidetty ohjaajan tärkeinä ominaisuuksina kommunikaatiotaitoja ja vuorovaikutustaitoja (Onuoha 1994; Cross 1995; MacDonald ym. 2001). Sen lisäksi Crossin (1995) tutkimuksessa ohjaajat ja alkuvaiheessa olevat opiskelijat pitivät erittäin tärkeänä sitä, että ohjaaja pystyi toimimaan hyvänä roolimallina ja häntä oli helppo lähestyä. Varttuneemmat opiskelijat arvostivat enemmän sitä, että ohjaaja oli perillä asioista kuin hyvää roolimallia. Opettajat pitivät erittäin tärkeänä sitä, että ohjaaja oli kiinnostunut opiskelijan oppimisprosessista ja huolestunut opiskelijan toteuttamasta potilaan hoidosta.

Opettajien ja ohjaajien näkemykset ovat usein ristiriitaisia siitä, mikä on heidän roolinsa opiskelijan ohjauksessa. Hentisen (1989) tutkimuksen mukaan vastuu opiskelijoiden oppimisesta nähtiin olevan opettajalla, vaikka hän ei jatkuvasti osallistunutkaan opiskelijoiden ohjaukseen. Ohjaajat näkivät omana ensisijaisena tehtävänään potilaiden hoitamisen ja harjoittelun ohjaus oli toisella sijalla.
Hayes ym. (1999) totesivat, että kun ohjaajien ja opiskelijoiden tarpeet ja odotukset eivät kohdanneet, seurauksena oli kommunikaatio ongelmia, opiskelijoilla esiintyi kiinnostuksen puutetta ja ohjaajat eivät kyenneet antamaan rakentavaa palautetta opiskelijoiden suorituksista.

Opiskelijat tuovat erityisesti esille ohjauksen toteuttamista dynaamisena, muuttuvana prosessina, jossa ohjaajan rooli ja mukana olo muuttuu, kun opiskelijan tiedot ja taidot lisääntyvät. Tavallisin toive koulutuksen alkuvaiheessa ja uusien harjoittelujaksojen alussa näyttää olevan se, että ohjaajat antaisivat konkreettista tukea potilastilanteissa, mutta loppuvaiheessa opiskelijat kaipasivat mahdollisuutta työskennellä itsenäisesti potilaiden kanssa (Oinonen 2000; Lähteenmäki 2001). Oleellista opiskelijoiden mielestä on se, että ohjaajat ja opettajat antavat riittävästi tilaa opiskelijoille kehittyä yksilöllisesti ja oppimisen lähtökohtina ovat opiskelijoiden omat tavoitteet ja itsearviointi (Raij 2000).

Koulun ja työelämän välinen yhteistyö ei välttämättä ratkea, jos pohditaan eri organisaatioissa olevien ohjaajien rooleja erikseen. Opiskelija kuljettaa koulusta työelämään tietonsa ja taitonsa, joita hänen pitäisi kyetä käyttämään asiakastyössä. Päivittäisessä työskentelyssä on mukana lähiohjaaja, joka oman harkintansa mukaan luotsaa opiskelijaa työn ääreen tietämättä, mitä asioita opettaja on oppilaitoksessa opettanut ja tärkeäksi todennut ammatillisessa kehittymisessä. Opiskelijan täytyy luoda kontakti vieraaseen työyhteisöön useaan kertaan opiskelunsa aikana ja hänen odotetaan selviytyvän erilaisissa yhteisöissä omaksumalla kunkin paikan työkulttuuri ja tavat.

Koulujen riittämätöntä osallistumista työharjoittelun toteuttamiseen harjoitteluympäristössä ovat nostaneet keskusteluun useat tahot. Opiskelijat ovat tuoneet esille, että opiskelijan, ohjaajan ja opettajan yhteisiä tapaamisia on liian vähän ja yksiomaan harjoittelujakson lopussa tapahtuvat tapaamiset ovat riittämättömiä, koska niissä vain todetaan tapahtuneet, eikä asioita käsitellä oppimista edistävästi (Oinonen 2000; Lähteenmäki 2001). Tärkeänä harjoittelun ohjauksen muotona Oinosen (2000) tutkimuksessa opiskelijat 
pitivät oman opiskelijaryhmänsä ja opettajan säännöllisiä tapaamisia harjoittelujakson aikana.

Terveysalan ammattikorkeakouluissa toteutetuissa arvioinneissa on todettu puutteita harjoittelupaikkojen ja koulujen välisessä yhteistyössä. Korkeakoulujen arviointineuvoston raportissa (Moitus ym. 2001, 46-47) todetaan, että oleellista pätevien työntekijöiden koulutuksessa on se, että opiskelijoiden harjoittelun sisältö vastaa harjoittelulle asetettuja tavoitteita ja kytkeytyy selkeästi osaksi hänen opintojaan. Asiantilanteen tehostamiseksi Korkeakoulujen arviointineuvosto kehottaa erityisesti ammattikorkeakouluja tiivistämään yhteistyötä harjoittelupaikkojen kanssa.

Myös Terveysalan korkeakoulutuksen arviointiraportissa arvioidaan kriittisesti terveydenhuollon harjoittelun toteutumista (Perälä \& Ponkala 1999). Opettajien todetaan osallistuvan entistä vähemmän opiskelijoiden harjoittelun ohjaukseen. Tilannetta huonontaa se, että harjoittelun ohjauksen voimavaroja on vähennetty terveydenhuollon toimintayksiköistä (Konkola 2001). Terveysalan korkeakoulutuksen arvioinnin seurantaraportissa (Ponkala 2001) todetaan, että ammattikorkeakouluissa ei ole kyetty lisäämään opettajien harjoittelun ohjaamiseen käyttämää aikaa, vaan paineita on edelleen käytännön harjoittelun ohjauksen tuntimäärien vähentämiseen.

\section{Fysioterapian työharjoittelun kokeiluja}

$\mathrm{V}_{\mathrm{k}}$ iime vuosina on Suomessa ammatillisessa koulutuksessa kiinnostuttu menetelmistä, joissa oppimisen keskeisinä lähtökohtina ovat ammatillisista käytännöistä nostettavat ongelmat (Poikela 2001). Näistä ongelmanratkaisuun perustuvista oppimistavoista (Problem-Based Learning, PBL) on kehitetty malleja, joissa eteneminen tapahtuu ennalta määritettyjen vaiheiden kautta. Tutkivan, uutta luovan oppimisen aikaansaamiseksi Hakkarainen ym. (2001) ehdottavat, että oppimisyhteisön kannattaisi organisoida toimintansa pikemmin tiedeyhteisön tapaan kuin ryhtyä opettamaan jotain tiettyä abstraktista, loogisen ajattelun tapaa.
Suomessa PBL opetus on niin uutta, ettei tutkimusta ole keritty tehdä, mutta fysioterapiassa löytyy joitakin ulkomaisia työharjoittelun kehittämiseen liittyviä kokeiluja, joissa opetusta on pyritty toteuttamaan ongelmanratkaisuna, vaikkakaan ei PBL mukaisesti. Opiskelijoiden teoreettisen tiedon ja käytännön taitojen kohtaamista, ongelmanratkaisutaitojen kehittymistä ja harjoittelupaikkojen ja oppilaitosten yhteistyötä on pyritty tehostamaan Australiassa kehitetyssä työharjoittelumallissa (Oldmeadow 1996) ja Torontossa käyttetyssä 'Physical Therapy Integrative Model' (PTIM) (Gasner \& Cleave-Hogg 1996).

Australiassa yliopisto ja harjoittelupaikka suunnittelivat yhdessä työharjoittelumallin, jossa opiskelijan kehittyminen on vaiheistettu etenemään noviisivaiheesta itsenäiseksi työntekijäksi (Oldmeadow 1996). Alussa opiskelija, jolla ei ole lainkaan kliinistä kokemusta, työskentelee ohjaajansa kanssa yhdessä. Asteittain ohjauksen määrää vähennetään ja viimeisten harjoittelujaksojen aikana opiskelija työskentelee täysin itsenäisesti. Opiskelijoiden ongelmanratkaisuun perustuva toimintatapa etenee potilaan oireiden tunnistamisesta ja arvioinnista tavoitteiden asetteluun, hoitotoimenpiteiden valintaan ja toteuttamiseen. Lopuksi tehdään kuntoutuksen jatkosuunnitelma, johon olennaisesti liittyy potilaan ohjaaminen. Kokeilun jälkeen opiskelijat arvioivat harjoittelumallia. He kokivat miellyttävänä harjoittelukäytännön erityisesti siksi, että siihen liittyi runsaasti ohjausta ja rakentavaa palautetta. Harjoittelun toteuttaminen kiinteässä yhteistyössä ohjaajan kanssa koettiin turvalliseksi tavaksi erityisesti harjoittelun alkuvaiheessa. Ohjaajat pitivät hyvänä sitä, että ohjelma edisti yhteistyötä koulun kanssa, mutta harjoittelumallia he pitivät varsin työläänä ja aikaavievänä.

Ohjelman suunnittelijat tulkitsivat kritiikin johtuvan siitä, että ohjaajat eivät olleet riittävästi sisäistäneet ohjelmaa ja ehdottivat ohjaajille lisäkoulutusta. Harjoittelumallille oli asetettu ensisijaisesti opiskelijan oppimista koskevia tavoitteita. Niinpä työläyteen saattaa olla myös syynä se, että malli on suunnattu erityisesti tehostamaan ohjaajan ja opiskelijan yhteistyötä, mutta 
sillä ei ole välttämättä ohjaajien työtä kehittäviä merkityksiä.

Toronton PTIM-kokeilun tavoitteena oli käytännön työn ja sen perustana olevan tiedon yhdistäminen opetuksessa siten, että oppilaiden oppimista pystyttäisiin parantamaan (Gasner \& Cleave-Hogg 1996). Kokeilussa 160 tunnin opintokokonaisuus suunniteltiin niin, että perinteisen luento-opetuksen osuutta vähennettiin ja osa opetuksesta siirrettiin tapahtuvaksi työpaikalla. Opettajat ja ohjaajat suunnittelivat opetuksen yhdessä, keskustelivat tavoitteista, tarvittavista tiedollisista perusteista ja terapiataidoista. Ohjaajat kokivat tehostetun yhteistyön oppilaitoksen kanssa hyvin myönteisenä ja näkivät opiskelijoiden hyötyneen lisääntyneestä ohjauksesta ja teorian ja käytännön integroinnista. Opiskelijat näkivät myönteisenä asiana erityisesti päätöksenteon tiedollisten perusteiden ja kriittisen ajattelun lisääntymisen sekä opiskelijakeskeisen ja yhdessä tapahtuneen oppimisen. PTIM-mallissa onnistuttiin rakentamaan oppilaitoksen ja työpaikan yhteinen aihekokonaisuus, jossa opettaja ja ohjaaja jakoivat vastuun opiskelijan oppimisesta. Opiskelija oli kuitenkin edelleen perinteisessä oppijan roolissa ja harjoittelulla ei ollut myöskään tässä mallissa työelämää uudistavaa tehtävää.

Ohjaajan ja opiskelijan välistä yhteistyötä ja harjoittelun tavoitteellisuutta ja suunnitelmallisuutta on kokeiltu Englannissa tekemällä opiskelijoiden kanssa oppimissopimus (learning contract) (Cross 1996). Tässä Birmingham lähestymistavaksi nimetyssä mallissa työharjoittelun ohjaaja ja opiskelija yhdessä pohtivat ja sopivat opiskelijan oppimisen kohteet ja tarpeet. Opiskelijat pitivät päiväkirjaa koko sopimuskauden ajan. Työharjoittelun ohjaaja otti vastuun opiskelijan päivittäisestä opetuksesta. Koulun opettajalla oli etäisempi merkitys oppimissopimuksessa. Hän kävi harjoittelupaikalla kerran viikossa, jolloin hän seurasi edistymistä ja toimi tukihenkilönä. Kun opiskelijoilta pyydettiin palautetta kokeilusta, yli puolet koki harjoittelusopimuksen auttavan heitä oman oppimisensa suuntaamisessa harjoittelutilanteissa. Loput opiskelijat katsoivat sopimuksesta olevan vain vähän tai ei ollenkaan hyötyä har- joittelussa. Tällaiset opiskelijat eivät pitäneet kovin tehokkaasti päiväkirjaa harjoittelunsa kulusta.

Harjoittelumalleissa on pystytty hyödyntämään harjoittelupaikkoja oppimisympäristöinä, joissa opiskelijat nostavat ongelmia käytännön potilastilanteista. Ohjaajille uudistukset ovat tuoneet lisää panostamista opiskelijaohjaukseen, minkä opiskelijat ovat kokeneet myönteisenä. Ohjaajille uudistukset saattavat olla työläitä, jos niiden ei koeta hyödyntävän kovin suuresti oman työn tekemistä. Vaikka koulun ja harjoittelupaikan yhteistyötä on pyritty lisäämään opetuksen yhteissuunnittelun kautta, koulun osuus harjoittelun toteuttamisessa jää usein ulkopuoliseksi. Opettaja on asiantuntija, joka vierailee harvakseen harjoittelupaikassa, mutta hän ei osallistu varsinaisesti harjoittelun toteuttamiseen.

\section{Kehittävät tiimit työssäoppimisen välineenä}

$\mathrm{T}$ yöharjoitteluun ovat tuoneet uudenlaisia näköaloja sellaiset työharjoittelumallit, joissa harjoittelua ei tarkastella vain opiskelijan ammatin oppimisen näkökulmasta, vaan työn sisällön kehittäminen ja siihen liittyvä oppimisen uudelleen järjestäminen ovat keskeisiä toiminnan kohteita. Tämä on merkinnyt oppilaitosten taholta sitä, että ne kehittävät opetussuunnitelmiaan erityisesti työelämäläheisiksi, etsivät uusia keinoja työelämäyhteyksiensä vahvistamiseksi ja opettajien työelämätuntemuksen ylläpitämiseksi sekä pyrkivät löytämään opiskelijoilleen hyviä työssäoppimispaikkoja ja sitoutuneita työpaikkaohjaajia (Räkköläinen 2001). TuomiGröhn (2000) käyttää koulun ja työpaikan toteuttamasta työssäoppimismallista nimitystä yhteistyötiimi silloin, kun yhteistyössä pyritään löytämään ja tuottamaan kehittyneempiä työtapoja ja -käytäntöjä. Ammattikäytäntöjen ja työn kehittämisen näkökulma tuo työpaikan ohjaajille uudenlaista merkitystä opiskelijaohjaukseen.

Terveysalan koulutuksissa on kokeiltu oppilaitoksen ja työpaikkojen yhteistyönä kehittämisprojekteja, joissa tavoitteena on ollut kehittävän 
siirtovaikutuksen aikaansaaminen. Kehittävän siirtovaikutuksen ajatuksena on siirrettävien tietojen ja taitojen yhdessä tapahtuva aktiivinen tulkinta, muokkaaminen ja uudelleenrakentaminen (Engeström 2001). Tuomi-Gröhn (2000) puhuu kehittävästä transferista, jonka tavoitteena on kehittää työpaikan toimintoja ja tuottaa opiskelijoille, ohjaajille ja opettajille välineitä uuden kohtaamiseen, jolloin tällainen yhteistoiminnallinen työtapa siirtyy tilanteesta toiseen sekä työpaikalla että oppilaitoksessa. Lähihoitajakoulutuksessa toteutetussa vuoden mittaisessa koulun ja harjoittelupaikan yhteistyöhankkeessa saatiin työpaikalla merkittäviä tuloksia aikaan (Tuomi-Gröhn 2001). Opettajat kokivat yksilöinä hyötyvänsä, samoin kuin opiskelijatkin, mutta oppilaitoksen hyödyt olivat vähäiset, opetuksen sisältö ja opetussuunnitelmat pysyivät ennallaan, eikä toimintamallia hyödynnetty oppilaitoksen muissakaan ohjelmissa.

Toimintaterapeuttikoulutuksessa toteutetussa harjoittelun kehittämisprosessissa on pystytty saamaan harjoittelun ohjaajia entistä tiiviimmin mukaan harjoitteluprosessiin ja hakemaan yhteisiä toiminnan kohteita työelämässä (Konkola 2001). Teorian ja käytännön yhdistämiseksi on luotu uusia oppimistehtäviä ja järjestetty oppimisstudioita. Konkola esittää uuden teoreettisen käsitteen, rajavyöhyketoiminnan, joka kuvaa uudenlaista yhteistyötä koulun ja työpaikan välillä. Hän kehittelee Wengerin (1998) esittämästä omien rajojen ylittymisestä käsitteen rajavyöhyke. Rajavyöhyke on kuvainnollisesti alue, joka vallitsee eri toimintajärjestelmien välissä, tässä tapauksessa koulun, työpaikan ja opiskelijan toimintajärjestelmän välissä. Rajavyöhyketoiminnan kehittämisen tarve lähtee siitä, että koulun ja työelämän välille on tarve luoda uudenlaisia käytäntöjä, jotka auttaisivat kehittävän siirtovaikutuksen tapahtumista. Tutkimuksessa todettiin, että toimintaterapeutti opettajien ja ohjaajien yhteiset kehittämisintressit liikkuvat pitkälti ammattialaan ja sen kehittämiseen ja oppimiseen liittyvissä kysymyksissä. Siten rajavyöhyketoiminnassa tekijä ei ole enää vain yksittäinen opiskelija, vaan esimerkiksi opiskelijan, toimintaterapeutin ja opettajan muodostama tiimi.
Yhteisen kohteen löytyminen saattaa olla ongelmallinen, jos koulun ja työpaikan näkemykset työnsä kohteesta ovat ristiriitaiset. Mäkisalon ja Kinnusen (1999) tutkimuksessa terveydenhuollon opettajat ovat käsitystensä mukaan ensisijaisesti vastuussa toiminnastaan opiskelijoille. Jos toiminnan kohde olisi opettajalla, ohjaajalla ja opiskelijalla sama, terveydenhuollon asiakas olisi silloin yhteinen asia.

Edellä mainitussa toimintaterapeuttikoulutuksen kehittämishankkeessa tutkittiin myös oppimistehtävän käyttöä ja erityisesti sen kehittävää siirtovaikutusta opiskelijoiden harjoittelussa (Lambert 2001). Tutkimuksessa nousi esille sellaisten oppimistehtävien rakentamisen vaikeudet, joilla voidaan samanaikaisesti hyödyntää koulua ja työpaikkaa. Oppimistehtävä jäi opiskelijan yksilötyöskentelyn välineeksi, eikä laajemmaksi yhteiseksi oppimisen kohteeksi.

Jos tavoitteena on saada kaikille osapuolille, opettajille, ohjaajille ja opiskelijoille, saada aikaan uusia ajattelu- ja työtapoja, joiden avulla saavutetaan työkäytäntöjen uusiutumista, työkokeilujen valossa näyttää vaikealta kaikkien tahojen tavoitteiden samanaikainen saavuttaminen. Selkeästi tuli esille tarve luoda sellainen yhteinen kehittämisen kohde, jonka kaikki osapuolet kokevat itselleen merkitykselliseksi. Oleellista on kiinnittää huomiota myös opetuksen ja yhteistoiminnan järjestämiseen niin, että oppiminen tuottaa todellisia, uusiutuneita toimintatapoja ja pysyviä muutoksia.

Kliininen ohjaaminen viittaa fysioterapeuttikoulutuksen järjestämiseen perinteisen sairauslähtöisen ajattelun mukaisesti, jossa fysioterapeutilla on ollut keskeinen rooli potilaiden harjoittelun toteuttamisessa. Uusien tarkastelutapojen kehittymiseen on kuitenkin tarvetta, erityisesti työn kohteen nostamisessa fysioterapiatoiminnan subjektiksi. Tämä edellyttää vanhojen toimintatapojen kriittistä tarkastelua ja uusien toimintatapojen kehittämistä. Muutos on kuitenkin syvemmältä luotaavaa kuin vain harjoitteluohjelmien muuttaminen, tarvitaan potilaan näkyväksi saattamista ja perinteisten totuttujen toimintatapojen ylittämistä. 
Fysioterapeuttikoulutuksessa on myös nostettu esiin siirtovaikutuksen aikaansaaminen. Hunt ym. (1998b) pitää tärkeänä sitä, että opetussuunnitelmissa esiintyy laajempia oppimisen tavoitteita kuin pelkästään pääaineeseen liittyvät erityiset taidot. Tällaiset yleiset taidot auttavat opiskelijaa paremmin hallitsemaan nopeasti muuttuvaa työtä, ammatillista ja sosiaalista ympäristöä ja varustavat opiskelijoita kohtaamaan muutoksen asettamat vaatimukset. Ammattiin koulutettavat opiskelijat pääsevät mukaan muutostyöhön oman ammatillisen kehittymisensä alkuvaiheesta alkaen, jos fysioterapian kehittäminen toteutetaan koulun ja työelämän yhteisenä hankkeena.

\section{Lähteet}

ASETUS ammattikorkeakouluopinnoista 1995. 3.3.1995/ 256.

CROSS, V. (1995) Perceptions of the ideal clinical educator in physiotherapy education. Physiotherapy 81, 506-513.

CROSS, V. (1996) Introducing learning contracts into physiotherapy clinical education. Physiotherapy 82, 21-27.

ENGESTRÖM, Y. (2001) Kehittävä siirtovaikutus: mitä ja miksi? Teoksessa T. Tuomi-Gröhn \& Y. Engeström (toim.) Koulun ja työn rajavyöhykkeellä. Uusia työssä oppimisen mahdollisuuksia. Helsinki: Yliopistopaino, 19-27.

GASNER, D. \& Cleave-Hogg, D. (1996) A model for integrative learning: Bringing the clinic into a subject-centred curriculum. Physiotherapy Theory and Practice 12, 103-112.

HAKKARAINEN, K., Lonka, K. \& Lipponen, L. (2001) Tutkiva oppiminen. Älykkään toiminnan rajat ja niiden ylittäminen. Helsinki: WSOY.

HAKKARAINEN, P. (1996) Teorian ja käytännön integrointi ammatillisessa aikuiskoulutuksessa. Teoksessa P. Lambert \& Y. Engeström (toim.) Kehittävä työntutkimus ammatillisissa oppilaitoksissa. Helsingin yliopiston kasvatustieteen laitoksen tutkimuksia 150, 3-33.

HAYES, K., Huber, G., Rogers, J. \& Sanders, B. (1999) Behaviors that cause clinical instructors to question the clinical competence of physical therapist students. Physical Therapy 79, 653-667.

HEATH, C. (1992) The delivery and reception of diagnosis in the general-practice consultation. Teoksessa P. Drew. \& J. Heritage (toim.) Talk at work. Interaction in institutional settings. Cambridge: Cambridge University Press, 235-267.

HEAVEN, C. \& Maguire, P. (1996) Training hospice nurses to elicit patient concerns. Journal of $\mathrm{Ad}$ vanced Nursing 23, 280-286.

HENTINEN, M. (1989) Kliininen opiskelu hoitamisen oppimisessa. Nykytilanne sairaanhoitajakoulutuksesta. Helsinki: Ammattikasvatushallitus.

HUNT, A., Adamson, B. \& Harris, L. (1998a) Physiotherapists' perceptions of the gap between edu- cation and practice. Physiotherapy Theory and Practice 14, 125-138.

HUNT, A., Higgs, J., Adamson, B. \& Harris, L. (1998b) University education and the physiotherapy professional. Physiotherapy 84, 264-272.

JORGENSEN, P. (2000) Concepts of body and health in physiotherapy: The meaning of the social/cultural aspects of life. Physiotherapy Theory and Practice 16, 105-115.

JÄRVINEN, A., Koivisto, T. \& Poikela, E. (2000) Oppiminen työssä ja työyhteisössä. Juva: WSOY.

KIVINEN. O. \& Silvennoinen, H. (2000) Koulussa ja työssä oppimisen ehdot ja mahdollisuudet. $A i$ kuiskasvatus 20 (4), 306-315.

KONKOLA, R. (2001) Harjoittelun kehittämisprosessi ammattikorkeakoulussa ja rajavyöhyketoiminta uudenlaisena toimintamallina. Teoksessa T. Tuomi-Gröhn \& Y. Engeström (toim.) Koulun ja työn rajavyöhykkeellä. Uusia työssä oppimisen mahdollisuuksia. Helsinki: Yliopistopaino, 148-186.

LAMBERT, P. (2001) Oppimistehtävät kehittävän siirtovaikutuksen tuottajina. Teoksessa T. TuomiGröhn \& Y. Engeström (toim.) Koulun ja työelämän rajavyöhykkeellä. Uusia työssä oppimisen mahdollisuuksia. Helsinki: Yliopistopaino, 96147.

LÄHTEENMÄKI, M-L. (2001) Fysioterapia ohjatussa harjoittelussa. Fysioterapian jäsentyminen fysioterapeutiksi opiskelun eri vaiheissa. Lisensiaattityö. Jyväskylän yliopisto, Terveystieteiden laitos.

MACDONALD, C., Houghton, P., Cox, P. \& Bartlett, D. (2001) Consensus on physical therapy professional behaviours. Physiotherapy Canada 53, 212219.

MIETTINEN, R. (2000) Konstruktivistinen oppimisnäkemys ja esineellinen toiminta. Aikuiskasvatus $20(4), 277-292$.

MOITUS, S., Huttu, K., Isohanni, I., Lerkkanen, J., Mielityinen, I., Talvi, U., Uusi-Rauva, E. \& Vuorinen, R. (2001) Opintojen ohjauksen arviointi korkeakouluissa. Korkeakoulujen arviointineuvoston julkaisuja 13. Helsinki: Edita.

MÄKISALO, M. \& Kinnunen, J. (1999) Opettajana terveydenhuolto-oppilaitoksessa. Opettajien käsityksiä omasta ja kollegojen toiminnasta. Aikuiskasvatus 19 (3), 231-243.

NEVILLE, S. \& Crossley, L. (1993) Clinical education: Perceptions of a clinical tutor's role. Physiotherapy $79,459-464$.

OINONEN, I. (2000) Harjoittelun ohjaus hoitotyön koulutuksen eri vaiheissa. Lahden ammattikorkeakoulun julkaisusarja A Tutkimuksia.

OLDMEADOW, L. (1996) Developing clinical competence: a mastery pathway. Australian Physiotherapy 42, 37-44.

ONUOHA, A. (1994) Effective clinical teaching behaviours from the perspective of students, supervisors and teachers. Physiotherapy 80, 208-214.

PERÄLÄ, M-L. \& Ponkala, O. (toim.) (1999) Tietoa ja taitoa terveysalalla. Terveysalan korkeakoulutuksen arviointi. Korkeakoulujen arviointineuvoston julkaisuja 8. Helsinki: Edita.

POIKELA, E. (2001) Ongelmaperustainen oppiminen yliopistossa. Teoksessa E. Poikela \& S. Öystilä (toim.) Tutkiminen on oppimista - ja oppiminen tutkimista. Tampere University Press, 101-117. 
PONKALA, O. (toim.) (2001) Terveysalan korkeakoulutuksen arvioinnin seuranta. Korkeakoulujen arviointineuvoston julkaisuja 11. Helsinki: Edita.

RAIJ, K. (2000) Toward a profession. Clinical learning in a hospital environment as described by student nurse. University of Helsinki, Department of Education. Research Report 166.

RICHARDSON, B. (1999) Professional development. Professional knowledge and situated learning in the workplace. Physiotherapy 85, 467-474.

ROBERTS, P. (1994) Theoretical models of physiotherapy. Physiotherapy 80, 361-366.

RÄKKÖLÄINEN, M. (2001) Ammatillisen oppilaitoksen ja työelämän yhteistyö - pohdintoja laadukkaan toiminnan perusteista. Teoksessa M. Räkköläinen \& I. Uusitalo (toim.) Työssäoppiminen ja ohjaus ammatillisissa oppilaitoksissa. Helsinki: Tammi, 33-47.

SAIRAALOIDEN ja terveyskeskusten kanssa tehtävät sopimukset käytännön opetuksesta (1983). Asetus ammattikorkeakouluopinnoista 337/502. 3.3.1994: Ammattikasvatushallitus.

SCHÖN, D. (1987) Educating the reflective practitioner. San Francisco: Jossey-Bass.

STACHURA, K. (1994) Professional dilemmas facing physiotherapists. Physiotherapy 80, 357-360.

TALVITIE, U. \& Reunanen, M. (2002) Interaction between physiotherapists and patients in stroke tre- atment. Physiotherapy 88, 77-88.

THORNQVIST, E. (1994) Profession and life: separate worlds. Social Science and Medicine 39, 701-713.

TUOMI-GRÖHN, T. (2000) Työssäoppimisen teoreettisia lähtökohtia. Katsaus erilaisiin transfer-käsityksiin. Aikuiskasvatus 20 (4), 325-331.

TUOMI-GRÖHN, T. (2001) Kehittävä siirtovaikutus koulun ja työpaikan yhteistyön tavoitteena tapaustutkimus lähihoitajien lisäkoulutuksesta. Teoksessa T. Tuomi-Gröhn \& Y. Engeström (toim.) Koulun ja työn rajavyöhykkeellä. Uusia työssä oppimisen mahdollisuuksia. Helsinki: Yliopistopaino, 28-66.

WENGER, E. (1998) Communities of practice. Learning, meaning, and identity. Cambridge: Cambridge University Press.

VIITANEN, E. (1997) Fysioterapian ammattikulttuuri terveyskeskuksissa. Acta Universitatis Tamperensis 577. Tampereen yliopisto.

Artikkeli saapui toimitukseen 14.11.2001. Se hyväksyttiin julkaistavaksi toimituskunnan kokouksessa 5-6.2002.

Edellä olevan artikkelin lisäksi Aikuiskasvatuksen tässä numerossa käsitellään oppimista työharjoittelun avulla myös kirja-arvioissa sivuilla 226-228 sekä Uutta tutkimuksestajaksossa sivuilla 245-251. 